\title{
Multiple Literacies Theory: how it functions, what it produces
}

\author{
Diana Masny*
}

\begin{abstract}
At the moment, there are two literacy theories that seem to dominate the research on literacies. They are known as the New Literacy Studies (NLS) (BARTON; HAMILTON; IVANIČ; 2002; STREET, 2003) and Multiliteracies (COPE; KALANTZIS, 2009). This article is about a different theory, Multiple Literacies Theory (MLT) that demarcates itself from them ontologically and epistemologically. It will also highlight aspects of NLS and Multiliteracies in order to point out the differences with MLT. This article aims to put forward the major concepts that underlie this theory and present vignettes from a study examining how perceptions of writing systems in multilingual children contribute to reading, reading the world and self as texts.
\end{abstract}

Keywords: Literacy. Reading. Writing.

* Diana Masny is Professor and director of the Multiple Literacies Research Unit at the Faculty of Education, University of Ottawa. 


\section{Introduction}

MLT and NLS share certain characteristics. Both are socially, culturally, historically, and politically situated. Literacies fuse with gender, race, religion, culture, and power. In addition, there may be links with a third literacies theory Multiliteracies in that literacies take on multiple meanings and are taken up as visual, oral, written and tactile. In that sense, manifestations of literacies are multimodal (COPE; KALANTZIS, 2009). The similarities end here.

When exploring a literacies theory, it is not enough to look at terms and determine that there is a common denominator. It is not uncommon to find theories that focus on multiplicity, multimodality and social situatedness. In order to find out what these different theories are about, it is important to examine what concepts associated with each theory (DUFRESNE; MASNY, 2005).

For example, one key concept in NLS is the literacy event and another key concept, this time related to Multiliteracies, is text. The former is an adaptation taken from Heath (1983) and ethnography of communication. An event refers to any occasion in which engagement with a written text is integral to participants' interactions and interactive processes (HEATH, 1983, p. 93). Texts as Kress and Van Leeuwen (2001) point out are multimodal which involves the interaction between the verbal and visual (MASNY; COLE, 2007). As you will see later on in this article, MLT conceptualizes events and texts differently. What is important to say is that each theory is paradigm specific with a conceptual framework which is ontologically and epistemologically driven. Accordingly, to link MLT with NLS or Multiliteracies is to assume that the three have one conceptual framework. This is not the case. Conceptualizations within MLT are paradigmatically related to poststructuralism.

\section{Multiple Literacies Theory (MLT)}

Within MLT, literacies are a construct (social, cultural, historical, physical assemblage). They consist of words, gestures, attitudes, ways of speaking, writing, valuing: ways of becoming with the world. They are about texts that take on multiple meanings and are taken up as visual, 
oral, written, tactile, olfactory, and in multimodal digital. They constitute texts, in a broad sense (for example, music, visual arts (painting, sculpting), physics, mathematics, digital remixes) that fuse with religion, gender, race, culture, and power, and that produce speakers, writers, artists, digital avatars: communities. Literacies are actualized according to a particular context in time and in space in which they operate. Given the nomadic tendencies of literacies; they are not wed to $a$ context, but are taken up in unpredictable ways across various contexts. In short, literacies (e.g. personal, community, school-based, digital, etc.) are about reading, reading the world, and self as texts. Reading is both intensive (disruptive) and immanent. Literacies involve constant movement - from a territory (of bounded stability) through a deterritorialization (a disruption) to a reterritorialization (on a different territory, a different mapping) - in the processes of becoming other.

\section{Reading, reading the world, and self as texts}

In reading, reading the world, and self, the work of Freire comes to mind. First, I take up Freire's notion that reading cannot happen without reading the world. I add to that as texts. For example, a drawing is a text that involves reading, reading the world. Second, just as reading cannot happen without reading the world, reading self as text cannot happen without reading the world. Reading self as text is about personal literacy. Third, Freire's purpose of introducing literacy comes with an endpoint, the emancipation of individuals. His theory of literacy is a theory of practice that serves to liberate and transform individuals; a sense of betterment of the human condition of the individual. MLT goes beyond Freire. There is no finality. MLT signals that transformations are taking place when tensions arise or as Dufresne (2002) states, when worldviews collide in the individual. What remains to be seen is how transformations happen, how they get taken up (MASNY, 2005).

\section{Reading}

Reading, according to Deleuze (1990), is asking how a text works and what it does or produces, not what it means. Reading is intensive and immanent. To read intensively is to read disruptively. To read immanently 
refers to the thought of reading and it is from investment in reading that a reader is formed. To read intensively and immanently extends the power to read differently and to think differently, to go beyond what is to what could be: difference and becoming (MASNY, 2009a).

Reading is about sense. Sense is not about interpretation; sense is an event that emerges (COLEBROOK, 2002). Sense is virtual. It is activated when, for example, words, notes and ad icons are actualized in situ and in interested ways. Take an example of an individual at who work smells coffee and it is four o'clock. The coming together of the smell of coffee and 4 o'clock disrupts (reading intensively) and brings on the thought of vacation, time to go home... (reading immanently). Sense expresses not what something is but its power to become.

\section{Literacies as processes}

By placing the emphasis on questions of how, MLT's focus is on the nature of literacies as processes. Current theories on literacies examine literacies as an endpoint, a product. While MLT acknowledges that books, Internet, equations, buildings are objects, sense emerges when relating experiences of life to reading, reading the world, and self as text. Accordingly, an important aspect of MLT is focusing on how literacies intersect in becoming. This is what MLT produces: becoming, that is, from continuous investments in literacies literate individuals are formed. A person is a text in continuous becoming. Reading, reading the world as text influences the text that a person continually becomes (DUFRESNE; MASNY, 2001).

\section{Investment and events}

In MLT, investment refers to connections of events stemming from experiences of life. Within MLT, events refer to "creations...selected and assessed according to their power to act and intervene rather than to be interpreted." (COLEBROOK, 2002, p. xliv). An event, according to Deleuze (1990), refers to life that produces lines of flight, moments that create ruptures and differences that allow creativity to take off along various planes, similar to a rhizome. It is from the continuous investment in literacies that individuals are formed as literate (MASNY, 2006). 


\section{Rhizome}

These transformations occur in a rhizomatic way. A rhizome has no center or grounding. Its connections grow and intersect. It signals neither beginnings nor endpoints, only entry and exit points that allow for more connections to be continuously created. It is critical to MLT. It allows for different literacies to intersect in complex and non-linear ways in time and space. A critical question to examining literacies in a rhizomatic way is to ask: how do they work? Transformations take on rhizomatic lines of flight involving literacies processes that impact becoming.

\section{Rhizoanalysis}

In this section, MLT is the theoretical lens used to examine how competing writing systems in learning literacies transform a child and becomes Other. The research questions are: How do reading, reading the world and self impact multilingual children's perceptions of writing systems? Conversely, how do perceptions of writing systems contribute to reading, reading the world and self?

Moreover, methodology is being taken up as a rhizomatic process that does not engage in methodological considerations in a conventional way. It resists temptations to interpret and ascribe meaning; it avoids conclusions. Data are read immanently and intensively and as sense becomes actualized it has a relationship to the text, but, unlike interpretation, it is not one of resemblance or representation or meaning. Deleuze (1995, p. 87) tells us, "Never interpret: experience, experiment." Accordingly rhizoanalysis views data as 'fluid and in flux', thus keeping the way open and working rhizomatic in-betweens to ask what connections may be happening between multiplicities (MASNY, 2009b).

In this article the complexity of these rhizomatic linkages is taken up in the form of selected vignettes around which questions are posed in juxtaposition with the theoretical framework. Each reading of 'data' texts and each selection of vignettes is an event wherein sense emerges; an immanent event suggesting not what data $i$, but rather how it might become. Remembering that within MLT, events "are seen as creations... selected and assessed according to their power to act and intervene." 
(COLEBROOK, 2002, p. xliv) we ask: What might the vignettes assembled here produce?

\section{Vignettes}

In this section, I will present three vignettes of children ages 6 and 7 years old to highlight how continuous investments in writing systems produce children as literate, how transformations through multiple literacies while reading, reading the world and self as texts contribute to becoming other.

\section{Anne}

Anne is 7 years old and in grade 2 at the time observations and interviews occurred in the classroom, at home, and at the daycare centre. Anne attends school where French is the language of instruction. She speaks, reads and writes fluently in French and English. Cantonese is the language spoken by both parents at home. Anne goes to French school because they have a daycare centre and the school is close to their home. To a lesser extent English is used in the home while French is the language used with her mother when doing homework. Her mother speaks French which is required as part of her job description as a civil servant in the Federal government.

An interview following a writing activity at the daycare centre:

$R$ : Earlier you talked about action words, you said when you write you need to use action words. What other words...

A: Adjective, I forgot what it means. The adjective describes. If I say a cow jumps over the fence...

A: Like sometimes I have too much French in my motor, a motor of words in my head and then all the English goes out. It is as if out-out out English! And then when it comes to saying hello in English I ask myself is it ishi eu poi chikpile and it is always like that.

$R$ : I don't quite understand

A: When I speak a lot of French, English goes out of my head. And then it goes to another person. And then the person says, "arghlarlara". 
Language is a bounded system. As such it is a territory. The tensions are operating between the two systems simultaneously. English goes out of her head. Is this the deterritorialization of English? This deterritorialization process entails going from the actual (territories) to the virtual (deterritorialization of English) as English goes out of her head and then gets reterritorialized in the actual (ishi eu poi chikpilé). This event would transform and create lines of flight and becoming. Moreover, Anne's last comment suggests that language is pre-personal. It is asignifying until it becomes part of the assemblage in another person's mind, sense emerges, and the assemblage produces the thought of language reterritorialized as "arghlarlara". Anne in this process of reading, reading the world and self transforms and becomes other.

\section{Cristelle}

Cristelle is also 7 years old and in the same grade 2 class with Anne. Cristelle's father speaks English while her mother speaks English and French. French is the mother's first language. Cristelle's mother stated that it is important that Cristelle receive a sound knowledge base in French before taking on reading and writing in English. Like Anne, she attends the daycare center.

In the vignette that follows, Cristelle's worldview has collided with that of the teacher (the importance of writing letters well). Cristelle produces what could be considered, 'vertical cartography' as she demonstrated for us in the figure below during an interview following a Language Arts period.

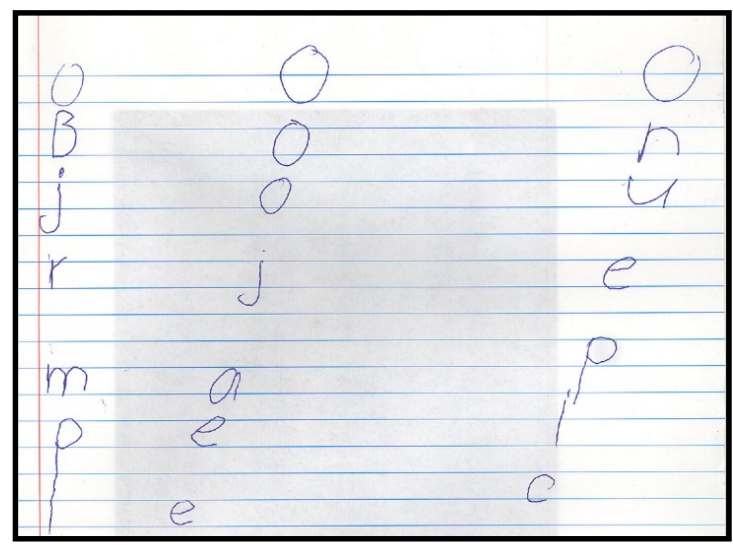


'Bonjour. Je m'appele' [Hello my name is]

$R$ : Last time you had a discussion with Danielle the research assistant and you said you like funny things. What do you mean?

C: I like to write like I see a big space.

$R$ : Would you show me how you wrote this?

$\begin{array}{lll}{[h} & m & C \\ e & i & a \\ l & s & l \\ l & t & l \\ o & e & o \\ & r & u]\end{array}$

C: I had one word here and then another there and I continued.

$R$ : What were you trying to say?

C: Hello, my name is Callou.

$R$ : And you chose to do it in this way?

C: Because I told Anne [her classmate] to look and Anne said, Cristelle, this not the way to write.

$R$ : And you chose to write this way?

$C$ : Yes and then after I erased it.

$R$ : Why did you want to write this way?

C: Because I like to be funny.

$R$ : What made you change your mind like this and after you erased?

C: Because Mrs. Moreau [the teacher] was coming over to see me.

$R$ : When she comes to see you, what do you do?

$C$ : She comes to correct.

$R$ : She comes to correct and-

$C$ : She looks at my paper.

$R$ : And what should you be doing?

C: Write a story, I mean you need to put the words together, stuck together. 
R: And so this is what you have to do when she comes. And you don't like to do that. What do you like to do?

$C$ : The same thing as that [pointing to the video clip].

$R$ : Do you often do stories like this?

C: No.

Writing is more flexible to Cristelle, she writes in 'funny' ways (like columns). Deterritorialization of writing conventions happens and creativity brings on (re)territorializations only to be deterritorialized and reterritorialized into conventions of the writing system as the teacher approaches. Anne does not seem to share Cristelle's enthusiasm for playful use of language. What are the possibilities of Cristelle's territorializations? What are the pedagogical implications for Cristelle and the forces of territorialization (e.g. standards of correctness in writing) in a school setting? In another interview, Cristelle says she knows her writing ought to be 'good writing,' that is, neat and between the margins and the blue lines; so she erases her spaced-out column writing when the teacher comes to look at her work. In Cristelle's understanding of writing systems, does desire as a assemblage of events manifest itself as a force of deterritorialization; disrupting conventional directions of writing? Are these de/reterritorializations the product of tension between her worldview and that of the teacher? How does this tension give rise to ruptures, lines of flight, the thought of transforming and becoming other?

\section{Estrella}

Estrella is 6 years old and in Grade 1. As her pseudonym indicates, Estrella speaks Spanish, Portuguese, French and English. Her mother is Mexican while her father is Portuguese. While it is easier to be exposed to English in a dominant English society in Ontario, Estrella's mother who speaks all four languages states that it is important to send her child to a French school because of the proximity in language structure to Spanish. It was her way to maintain 'survival of the Spanish language' (mother's words) along with support in Spanish and Portuguese Estrella was receiving in the home.

Following a science period: 
R: What do you like to write in science?

E: I like to write a lot. In science it is very different from writing a book.

R: What is different?

E: You do not tell a story or a legend, and there are different words. And also you learn a lot of things.

R: You said there were different words. What do you mean?

E: They are not the same words. I was writing a story and you were. I was writing "it was so cold. It was so cold."

$R$ : How is it different writing in science?

E: The difference is that this is a story and that is an experiment and the words are different. It is not like: "It was so cold"

C: What are the different words in science?

E: It is like story telling... It is the real world [science]. This [story] is not the real world. I just wrote a story: "Sylva wakes up and says; oh kitty look the Rideau canal is open." It is different because it is a story.

R: Now let's return to the science activity. You use different words.

E: There are no such words and Sylva isn't there. It is an experiment. A story is not like science and a story doesn't make you learn things. Sometimes there are real stories, like there was a boy and he climbs the mountain and falls from a glacier into a hole, stays there and he dies and people learn things sometimes...

$R$ : When writing in science what do you have to do?

E: You have to say that this is an experiment, how we did it and how it was, how it becomes something.

$R$ : And do you use the same words [as for storytelling]

E: No, the book, things and experiments there is a big difference. I have lots of fun with the book because it is for storytelling. There are drawings. In an experiment there are no drawings, just the experiment and we have lots of fun.

* In the French period, children were read the story, Il fait si froid. Children were then asked to create a story using the original story as an entry point to create their own. In the original story, the main character was a boy called Sylvain. In Estella's creation, the main character is a young girl called Sylva. 
$R$ : How do you know which words to use?

E: It is very difficult to explicate [expliquer]. My head takes the information. It knows what to do and what to write. Then it sends to the hand that uses a pencil and after I write it and my mouth I have to say what I must do and then it brings [rend] the message here...yes, it is very difficult. It goes to the mouth and then the ear listens and then the ear gives after a long time and the head sees that and then the mouth says it and after the ear it goes to the head and then it has to go to my hand knows what to do when it hears. It is very difficult because my hand. It understands from my hand and that's all.

This vignette offers a perspective of deterritorialization and the space different territories (storytelling and science) take up in the classroom, how they function and what they do. Regarding the first part of the vignette, it seems that Estrella knows what goes into the territories for storytelling and science activity. They are different territories. One important element in stories is that they are not about the real world most of the time. Stories come in a book with drawings. Science is about experiments and they are part of the real world and they are about learning things. What does science do? Could it be "about learning" that transforms life? While "science is about making the world function and manageable, literature is the power of fiction itself: not making a claim about what the world is, but about the imagination of a possible world." (COLEBROOK, 2002, p. 12). Drawing on Deleuze and Guattari (1994) regarding science and literature, what are the productive forces at work that invest Estrella as literate?

In the second part of the vignette, Estrella's description of the writing process through a Deleuzian lens seems to be a sense of the 'out of body' in Estrella's literacy engagement. She describes how parts of the body, hand, ear, mouth, are deterritorialized and transform into communications tools. She is not the one controlling writing. Instead Estrella is caught up in a flow of events - experiences, connections - and becoming other. How does her head know which information is required? Might it be related to an assemblage of events? Are the productive forces of desire as an assemblage creating Estrella as literate? Estrella is the effect of reading, reading the world and self in the context of a science activity and a language arts activity. 


\section{Lines of flight, creativity and becoming}

This article aims to complicate and disrupt what teaching and learning language and literacies entail. The vignette with Estrella in class suggests an awareness of the writing process, and conceptualization of stories and science. The vignette with Anne points to perceptions of multiple writing systems. The vignette with Cristelle offers a disruptive reading going on in untimely ways. In all of these, was it the thought of (immanence); how each block of writing led to others and each time, what the literacies produce: transformation and becoming? Opening up writing systems opens up lines of creativity; going beyond the immediate boundaries of texts, optimizing creativity so that connections made are part of the processes of transformation and becoming through multiple literacies. Experiences assembled in and across different contexts are complex and multilayered and contribute to sense making while reading, reading the world, and self.

What are the pedagogical implications? There is more to literacy than what continues to inform school practices. Literate practices are multiple, occurring at home, in school and in the community (MASNY, 2009b). This study showed how a learner is an effect of continuous investment in multiple writing systems. It could also enrich thinking about the complexity of rhizomatic connections and processes involved in becoming with multiple literacies. Finally, this study offers the possibility of informing and transforming pedagogies within language and literacies classrooms and programs based on the notion that learning presupposes an encounter with something as yet unknown (SEMETSKY, 2003). Accordingly, teaching is about "attempting to induce an encounter with the new [and] ... an undoing of orthodox connections." (BOGUE, 2004, p. 341). As different connections form in this disruptive process of de/reterritorialization, becoming and learning take place. Creative processes allow literacies to move beyond, extend, and transform multiple literacies and learners. This research provides a different avenue to literacies research. The Multiple Literacies Theory retained in this article becomes a way to examine how out of complexity and multiplicity, in untimely ways, differences are continuously transforming in becoming other. MLT allows us to think about life and how one might live through difference and becoming in reading, reading the world and self. 


\section{REFERENCES}

BARTON, D.; HAMILTON, M.; IVANIC, R. (Ed.). Situated literacies. London: Routledge, 2002.

BOGUE, R. Search, swim, and see: Deleuze's apprenticeship in signs and pedagogy of images. Educational Philosophy and Theory, United Kingdom, v. 36, n. 3, p. 327-342, 2004.

COLEBROOK C. Deleuze. New York: Routledge, 2002.

COPE, B.; KALANTZIS, M. “Multiliteracies:" new literacies, new learning. Pedagogies: an international journal, United States, v. 4, n. 3, p. 164-195, july 2009.

DELEUZE, G. Negotiations, 1972-1990. New York: Columbia University Press, 1995.Original work published 1990.

DELEUZE, G. The logic of sense. New York: Columbia University Press, 1990. Original work published 1969.

DELEUZE, G.; GUATTARI, F. What is Philosophy? London, U.K.: Verso, 1994.

DUFRESNE, T. Through a lens of difference or when worlds collide: a poststructural study on error correction and focus-on-form in language and second language teaching. 2002. 376 leaves. (Doctoral Thesis Education) - Faculty of Education, University of Ottawa, Ottawa, Canada, 2002.

DUFRESNE, T.; MASNY, D. The makings of minority education: the Québec educational curriculum reforms. In: CONGRESS OF THE HUMANITIES AND SOCIAL SCIENCES, 3., 2001, Québec. Annais... Quebec: Université de Laval, 2001.

DUFRESNE, T.; MASNY, D. Different and differing views on conceptualising writing system research and education. In: COOK, V.; BASETTI, B. (Ed.). Second language writing systems. Clevedon, UK: Multilingual Matters Ltd. 2005. p. 375-397.

HEATH, S. B. Ways with words. New York: Cambridge University Press, 1983. 
KRESS, G.; VAN LEEUWEN, T. Multimodal discourse: the modes and media of contemporary communication. London: Hodder Arnold Publication, 2001.

MASNY, D. Bridging access, equity and quality: the case for multiple literacies. In: ANNUAL CONFERENCE OF THE AUSTRALIAN ASSOCIATION OF TEACHERS OF ENGLISH AND LITERACY, 2009, Tasmania. Proceedings...

TASMANIA, 2009B. From: <http://www.englishliteracyconference.com. $\mathrm{au} /$ files/documents/hobart/conferencePapers/refereed/MasnyDiana.pdf>. Retrieved: june 22, 2010.

MASNY, D. Multiple literacies: an alternative or beyond Freire. In: ANDERSON, J. et al. (Ed.). Portraits of literacy across families, communities, and schools: intersections and tensions. Mahwah, NJ: Erlbaum, 2005. p. 171-184.

MASNY, D. Learning and creative processes: a poststructural perspective on language and multiple literacies. International Journal of Learning, Australia, v. 12, n. 5, p.149-156, 2006.

MASNY, D. Literacies as becoming: a child's conceptualizations of writing systems. In: MASNY, D.; COLE, D. R. Multiple literacies theory: a Deleuzian perspective. Rotterdam, The Netherlands: Sense Publishers, 2009a. p. 13-30.

MASNY, D.; COLE, D. Applying multiple literacies in Australian and Canadian contexts. In: SIMPSON, A. (Ed.). Future directions in literacy: International Conversations Conference Proceedings. Sydney, Australia: Sydney University Press, 2007. p. 190-211. From: <http://www.ses. library.usyd.edu.au/>. Retrieved: May 22, 2009.

SEMETSKY, I. The problematics of human subjectivity: Gilles Deleuze and the Deweyan legacy. Studies in Philosophy and Education, Netherlands, v. 22, n. 3/4, p. 211-225, 2003.

STREET, B. What's new in the New Literacy Studies? critical approaches to literacy in theory and practice. Current Issues in Comparative Education, New York, v. 5, n. 2, p. 77-91, mar./may 2003. From: <www.tc.columbia. edu/cice/Archives/5.2/52street.pdfs. Retrieved: june 22, 2009 


\section{Teoria dos letramentos múltiplos: como funciona e o que produz}

\section{Resumo}

No momento existem duas teorias do letramento que parecem dominar as pesquisas sobre o tema. Elas são conhecidas como Novos Estudos em Letramento (New Literacy Studies $N L S)$ (BARTON; HAMILTON; IVANIC; 2002; STREET, 2003) e Multiletramentos (COPE; KALANTZIS, 2009). Este artigo é sobre uma teoria diferente, a Teoria dos Letramentos Múltiplos (Multiple Literacies Theory - MLT) que se destaca das outras ontologicamente e epistemologicamente. O texto irá também sublinhar aspectos dos Novos Estudos em Letramento e os Multiletramentos, de maneira a evidenciar as diferenças com a Teoria dos Letramentos Múltiplos. Este artigo tem como objetivo impulsionar os principais conceitos subjacentes a esta teoria e apresentar vinhetas de um estudo examinando como percepçóes dos sistemas de escrita em crianças multilingues contribuem para a leitura, a leitura do mundo e de si mesmo enquanto textos.

Palavras-chave: Letramento. Leitura. Escrita.

\section{Teoría de las literacidades múltiplas: cómo funciona y lo que produce}

\section{Resumen}

En la actualidad existen dos teorías de literacidad que parecen dominar las investigaciones sobre el tema. Ellas son conocidas como "Nuevos estudios en Literacidad" (New Literacy Studies - NLS) (BARTON; HAMILTON; IVANIC; 2002; STREET, 2003) y "Multiliteracidades" (COPE; KALANTZIS, 2009). El presente artículo es sobre una teoría diferente; Teoría de las Literacidades Múltiplas (Multiple Literacies Theory-MLT) que se diferencia de las otras ontológicamente y epistemológicamente. El texto también evidenciará las diferencias que existen entre los Nuevos estudios en Literacidad y las Multiliteracidades con la teoría aquí propuesta. También este artículo tiene como objetivo estimular los principales conceptos subyacentes en esta teoría presentar vińetas de un estudio examinando como la percepción de los sistemas de escritura en niños y niñas multilingües contribuye para la lectura, la lectura del mundo y de sí mismo en cuanto textos.

Palabras clave: Literacidad. Lectura. Escritura. 


\section{Diana Masny}

Faculty of Education, University of Ottawa.

http://www.litteratiesmultiples-multipleliteracies.ca/

E-mail:dmasny@uottawa.ca

Recebido em: $1 / 7 / 2010$

Aprovado em: 10/10/2010 